\title{
Particular Effect Of Leadership Style, Work Environment, And Motivation On Employee Performance Of During The Covid-19 Pandemic
}

\author{
Fauzan Dahlan $^{1 *}$, Setyo Riyanto ${ }^{2}$ \\ ${ }^{1,2}$ Faculty of Economics and Business, Mercu Buana University ${ }^{1,2}$ \\ ${ }^{*}$ Corresponding author: \\ Email: fauzanmetrotv@gmail.com
}

\begin{abstract}
.
This study aims to determine how much influence leadership style, work environment, and motivation have on the performance of PT. Djaya Sinar Propertindo employees during The Covid-19 pandemic.The population in this study amounted to 100 people, while in determining the sample used The Slovin's Formula with a 5\% sample which obtained a sample of 80 employees. This research was conducted from November 2020 to April 2021. The data were collected using quantitative methods and the analysis used was the data instrument test, classical assumption test, multiple regression analysis, coefficient of determination, and hypothesis testing using SPSS v.25 for windows.Based on the study results, it can be concluded that: hypothesis testing, The F-count is 34,636. In comparison, The F-table is 2.72, which means F-count $>$ F-table. This result shows that Ho is rejected and $\mathrm{Ha}$ is accepted. The result means that leadership style, work environment, and motivation simultaneously significantly affect employee performance at PT. Djaya Sinar Propertindo.
\end{abstract}

Keywords: Leadership Style,Work Environment, Employee Motivation, and Performance

\section{INTRODUCTION}

In the current era of Covid-19 and new normal modernization, companies are required to be more responsive to all developments that occur to survive, continue to grow, and achieve their goals. Every company has a desire to improve high employee performance. Therefore, if employee performance can compete, the company can compete with other companies. In achieving the company's desired performance, one crucial component is human resources or individuals as members of the organization.Human resource is an essential asset in a company that must be elevated to improve company performance. Success in achieving these goals depends on the ability of employees to operate work programs within the organization. In this case, quality human resources will contribute to the company. Unfortunately, in the development of today's era, many companies compete for profits to develop so that companies are required to have quality human resources.Every company often faces problems regarding the performance of its employees. Every leader in the company will always strive to achieve maximum results and is carried out effectively and 
efficiently. In order to achieve the desired level of effectiveness and efficiency, the company must have a sound work performance system.

Therefore, the organization's success depends on the good or bad performance of the employees, who are the driving factor for the running of a company. Employee performance will directly impact the progress or setbacks obtained from the company.Leadership style is one factor that influences the performance of human resources in an organization, so good management depends on it. The leadership style plays a crucial role in influencing so that they have the desire to work effectively and influence the success of the organization or company in achieving goals. The success of a company either partially or wholly depends on the quality of the leadership itself because a leader has the power to regulate his employees to do something to achieve company goals. Thus, companies need leaders who can inspire, motivate and move members of their organizations effectively and efficiently for company goals. Robbins (2006:432) argues that leadership can influence the group towards achieving goals. The work environment is also a factor that is no less important in influencing employee performance. The work environment is very influential around employees in a company, both physical and non-physical. The work environment directly influences employees in completing their responsibilities to the company.

If the employee is comfortable with the work environment, then the employee will feel at home in his workplace to carry out activities and complete his duties and responsibilities.Suprayitno and Sukir (2007:25) state that "Creating a pleasant work environment that can meet the needs of employees will give them a sense of satisfaction and encourage their morale. On the other hand, a work environment that does not get enough attention will negatively impact morale. This harmful excess is because employees in carrying out their duties experience interference, so they are less enthusiastic and do not devote their energy and thoughts to their duties." Therefore, a conducive environment is expected to improve employee performance. Conversely, if the work environment is inadequate or not conducive, this can reduce employee performance.In improving employee performance, it is necessary to have motivation. Motivation is the drive, driving force that causes an action or deed. In addition, motivation is an excellent example to move and build one's character in order to influence employees to behave towards their work. Therefore, companies need Human Resources who have high motivation to provide good performance and are enthusiastic about achieving high work performance.

Work motivation is a process that shows individual intensity, direction, and persistence as an effort to achieve company goals. Vroom (2002) states that motivation refers to influencing individual choices towards various forms of desired activity.Lack of motivation from a leader to his employees will lead to an attitude that will show a sense of laziness at work and a less severe attitude towards their tasks. So that employees can work seriously, a leader should provide motivation such as giving awards to employees who work optimally. In addition, the need for stimulus or stimuli 
such as performance allowances, bonuses given by the company to employees will make employees motivated to complete work very well.PT. Djaya Sinar Propertindo is a company engaged in providing labor services, construction, cleaning services as well as providing goods and services. This company has four divisions such as Coal Ash Handling, Mechanical Helper, Landscape Man Power (Civil), and Dulevo Driver. PT. Djaya Sinar Propertindo makes several policies that must be followed by all employees, such as Check-in hours are at $08.00 \mathrm{WIB}$, leaving at 17.00 WIB, and for working days Monday to Friday. It is expected that employees do not violate the company's rules. If the employee violates the policies that have been set, there will be consequences that the employee must accept.

\section{LITERATURE REVIEW AND HYPOTHESES DEVELOPMENT Leadership}

\section{Definition of Leader and Leadership}

The concept of "pemimpin" comes from the foreign words "leader" and "kepemimpinan" from "leadership." Leaders are the most results-oriented people globally, and the certainty of this outcome is only positive when a person knows what he or she wants.Kouzes (2004:17) says that leaders are pioneers as people who are willing to step into unknown situations. In addition, leaders who have a clear vision can be role models in carrying out their primary duties and functions as leaders. Robbins (2006:432) states that leadership is the ability to influence the group towards achieving goals.Kartono (2005:153) states leadership is "the ability to give constructive influence to others to make a cooperative effort to achieve the goals that have been planned."

Based on the explanation of the definition of leadership, several conclusions can be drawn, namely that:

1. Leadership involves the use of influence, and that all relationships can involve leadership.

2. Leadership includes the importance of the communication process. The clarity and accuracy of the communication affect the behavior and performance of followers.

3. Leadership focuses on the goals achieved. Therefore, influential leaders must relate to the individual, group, and organizational goals.

\section{Work environment}

\section{Understanding Work Environment}

The work environment is around the work and can affect them in carrying out the assigned tasks and has a significant influence on employee performance. Employees will be able to carry out their work well and achieve optimal results if supported by an appropriate environmental condition. The work environment dramatically affects employees' work performance because a good and pleasant work environment will be able to provide encouragement or morale for employees so that employees can excel and their work performance will be better. 
The following are some definitions of the work environment put forward by experts:

According to Budianas (2012:2)

"The work environment is the components refer to institutions or forces that interact directly or indirectly according to a certain pattern regarding the organization or company that will not be separated from the environment in which the organization or company is located."

\section{According to Sedarmayanti (2011:2)}

"The work environment is the whole of tools and materials encountered, the surrounding environment in which a person works, his work methods, as well as good work arrangements as individuals or as a group."

From the various studies above, it is concluded that the work environment is a workplace condition around employees with supporting facilities and infrastructure, such as adequate lighting, work facilities, and tools, as well as conducive communication relationships that can improve employee performance. Besides that, good working environment conditions will support workers to be happy with their workplace. The feeling of being happy with the workplace will create a feeling of satisfaction in the hearts of its employees and will lead to good morale so that employee performance increases and company goals are achieved.

\section{Work Motivation}

\section{Understanding Motivation}

Motivation comes from the Latin word "Movere," which means encouragement, a driving force that causes an action or deed. In English, the word "Movere" is often matched with the term "Motivation," which means giving motives, generating motives, or things that cause encouragement or circumstances that cause encouragement. Armstrong (2009) states that motives are reasons for doing something. Motivation relates to the strength and direction of behavior and the factors that influence a person to behave in a certain way. The term motivation can refer to the various goals that individuals have, how individuals choose goals, and how others try to change their behavior. The three components of motivation are:

a) Direction, what people are trying to do;

b) Effort, how hard one tries;

c) Persistence, how long a person keeps trying.

Based on the understanding that has been described motivation, it can be concluded that what is meant by work motivation is the behavior and factors that influence employees to behave towards their work. Therefore, work motivation is a process that shows individual intensity, direction, and persistence to achieve organizational goals. 


\section{Performance}

\section{Understanding Performance}

Performance in English is called job performance or actual performance or level of performance, which is the level of success of employees in completing their work. Performance is the embodiment of ability in the form of actual work. Performance is the result of work achieved by employees in carrying out tasks and jobs that come from the organization.Rivai and Sagala (2009) state that performance is an actual behavior displayed by everyone as employees produce work performance according to their role in the organization.Benardin and Russell (2000) stated that performance is produced by certain job functions or activities at specific jobs during a certain period. The work results are the result of the abilities, skills, and desires achieved.Milkovich and Boudreau (1997) state that performance is the level at which employees carry out their work by predetermined conditions.

\section{Research Hypothesis}

The design hypotheses that will be tested in this study are four hypotheses, including:

\section{Hypothesis 1}

H1: It is suspected that there is a positive and significant influence between Leadership Style on Employee Performance at PT. Djaya Sinar Propertindo.

\section{Hypothesis 2}

H2: It is suspected that there is a positive and significant influence between the Work Environment on Employee Performance at PT. Djaya Sinar Propertindo.

\section{Hypothesis 3}

H3: It is suspected that there is a positive and significant influence between motivation on employee performance at PT. Djaya Sinar Propertindo.

\section{Hypothesis 4}

H4: It is suspected that there is a positive and significant influence between Leadership Style, Work Environment, and Motivation on Employee Performance at PT. Djaya Sinar Propertindo.

\section{METHODS}

\section{Population and Sample}

\section{Research Population}

Sugiyono (2013:114) states that: "the population is a generalization area consisting of objects and subjects that have certain qualities and characteristics that are determined by researchers to be studied and then drawn conclusions" in this study, the population is employees at PT Djaya Sinar Propertindo who are totaling 100 people.

\section{Sample}

Sugiyono (2013:116) states that the sample is part of the Number and characteristics possessed by the population ". This statement means that there will be 
no sample if there is no population. The sample size is used by the author based on the consideration of using The Slovin's Formula as quoted by Husain Umar (2003:108)

$$
\mathrm{n}=\mathrm{N} /(1+\mathrm{N}(\mathrm{e}) 2)
$$

Information :

$\mathrm{n}=$ Number of samples sought

$\mathrm{N}=$ Population size

$\mathrm{e}=$ The value of the margin of error (size of error) of the population size

Sampling 5\%

$$
\begin{aligned}
& \mathrm{n}=\mathrm{N} /\left(1+\mathrm{N}(\mathrm{e})^{2}\right) \\
& \mathrm{n}=\left(100 /\left(1+100(0,05)^{2}\right)\right. \\
& \mathrm{n}=(100 /(1+100(0,0025) \\
& \mathrm{n}=100 / 1,25 \\
& \mathrm{n}=80 \text { people. }
\end{aligned}
$$

\section{RESULTS AND DISCUSSIONS}

This study first tested the validity of the data with the following results :

\section{Validity test}

\begin{tabular}{|c|c|c|c|}
\hline Item & $\mathbf{r}_{\text {-count }}$ & $\mathbf{r}_{\text {-table }}$ & Descriptions \\
\hline LS1 & 0,706 & 0,219 & Valid \\
\hline LS2 & 0,676 & 0,219 & Valid \\
\hline LS3 & 0,574 & 0,219 & Valid \\
\hline LS4 & 0,561 & 0,219 & Valid \\
\hline LS5 & 0,412 & 0,219 & Valid \\
\hline LS6 & 0,531 & 0,219 & Valid \\
\hline LS7 & 0,644 & 0,219 & Valid \\
\hline LS8 & 0,503 & 0,219 & Valid \\
\hline LS9 & 0,455 & 0,219 & Valid \\
\hline Item & r-count & r-table & Descriptions \\
\hline WE1 & 0,788 & 0,219 & Valid \\
\hline WE2 & 0,865 & 0,219 & Valid \\
\hline WE3 & 0,773 & 0,219 & Valid \\
\hline WE4 & 0,781 & 0,219 & Valid \\
\hline WE5 & 0,747 & 0,219 & Valid \\
\hline WE6 & 0,510 & 0,219 & Valid \\
\hline WE7 & 0,769 & 0,219 & Valid \\
\hline WE8 & 0,618 & 0,219 & Valid \\
\hline WE9 & 0,694 & 0,219 & Valid \\
\hline Item & r-count & r-table & Descriptions \\
\hline M 1 & 0,613 & 0,219 & Valid \\
\hline M 2 & 0,665 & 0,219 & Valid \\
\hline M 3 & 0,790 & 0,219 & Valid \\
\hline M 4 & 0,776 & 0,219 & Valid \\
\hline M 5 & 0,757 & 0,219 & Valid \\
\hline M 6 & 0,694 & 0,219 & Valid \\
\hline M 7 & 0,679 & 0,219 & Valid \\
\hline & & &
\end{tabular}




\begin{tabular}{|c|c|c|c|}
\hline M 8 & 0,629 & 0,219 & Valid \\
\hline M 9 & 0,635 & 0,219 & Valid \\
\hline Item & r-count & r-table & Descriptions \\
\hline P1 & 0,685 & 0,219 & Valid \\
\hline P2 & 0,673 & 0,219 & Valid \\
\hline P3 & 0,562 & 0,219 & Valid \\
\hline P4 & 0,855 & 0,219 & Valid \\
\hline P5 & 0,776 & 0,219 & Valid \\
\hline P6 & 0,741 & 0,219 & Valid \\
\hline P7 & 0,621 & 0,219 & Valid \\
\hline P8 & 0,608 & 0,219 & Valid \\
\hline P9 & 0,620 & 0,219 & Valid \\
\hline
\end{tabular}

Source: SPSS V 25 Data Processing Results

Based on the table above, it can be seen that each statement for X1, X2, X3, and $\mathrm{Y}$ is declared valid because the $\mathrm{r}$ count is greater than the $\mathrm{r}$ table with a significant level of $5 \%$, namely 0.219 . So it can be concluded that the data in the variables $\mathrm{X} 1, \mathrm{X} 2$, $\mathrm{X} 3$, and $\mathrm{Y}$ are feasible to be used as research data.

Reliability Test

\begin{tabular}{|c|c|c|c|}
\hline Variables & $\begin{array}{c}\text { Cronbach's } \\
\text { Alpha Score }\end{array}$ & $\begin{array}{c}\text { Correlation } \\
\text { Coefficient }\end{array}$ & Descriptions \\
\hline Leadership Style $\left(\mathrm{X}_{1}\right)$ & 0,730 & 0,600 & Reliable \\
\hline Work Environtment $\left(\mathrm{X}_{2}\right)$ & 0,883 & 0,600 & Reliable \\
\hline Motivation $\left(\mathrm{X}_{3}\right)$ & 0,859 & 0,600 & Reliable \\
\hline Performance $(\mathrm{Y})$ & 0,855 & 0,600 & $\mathrm{j}_{\text {le }}^{\text {Reliab }}$ \\
\hline
\end{tabular}

Source: SPSS V 25 Data Processing Results

Based on the test results, the Cronbach's Alpha Value> Correlation Coefficient 0.600 (scale of thumb usually) means that all research variables are reliable because the alpha value of each variable is greater than the r-table value so that it can be used for additional test materials.

\section{Hypothesis T Test}

Coefficients

\begin{tabular}{|c|c|c|c|c|c|c|c|c|}
\hline & \multirow{2}{*}{ Model } & \multicolumn{2}{|c|}{$\begin{array}{l}\text { Unstandardized } \\
\text { Coefficients }\end{array}$} & \multirow{2}{*}{$\begin{array}{c}\begin{array}{c}\text { Standardized } \\
\text { Coefficients }\end{array} \\
\text { Beta }\end{array}$} & \multirow{2}{*}{$\mathbf{t}$} & \multirow{2}{*}{ Sig. } & \multicolumn{2}{|c|}{$\begin{array}{c}\text { Collinearity } \\
\text { Statistics }\end{array}$} \\
\hline & & B & $\begin{array}{l}\text { Std. } \\
\text { Error }\end{array}$ & & & & Tolerance & VIF \\
\hline \multirow[t]{4}{*}{1} & (Constant) & .848 & 3.963 & & .214 & .831 & & \\
\hline & LS & .343 & .159 & .249 & 2.152 & .035 & .415 & 2.409 \\
\hline & WE & .267 & .093 & .264 & 2.878 & .005 & .659 & 1.518 \\
\hline & $\mathrm{M}$ & .361 & .117 & .363 & 3.088 & .003 & .401 & 2.491 \\
\hline
\end{tabular}

a. Dependent Variable: KK

Source: SPSS V 25 Data Processing Results

a) Based on the statistics above, the t-value for the leadership style variable is 2.152. This result means that it is greater than the table value, which is 1.991 , obtained from ( $\mathrm{n}-\mathrm{k}=80-4=76$ ) with a significance level of $\mathrm{a}=5 \%$. Then the sig value is obtained at 0.035 , which means it is smaller than the significance level $\mathrm{a}=0.05$. 
Therefore, it is concluded that $\mathrm{t}$ count $>\mathrm{t}$ table $(2.152>1.991)$. Furthermore, the significance level is $0.035<0.05$, so the decision is taken $\mathrm{HO}$ is rejected, and $\mathrm{Ha}$ is accepted. This result means that the independent variable (leadership style) has a positive and significant effect on the dependent variable (employee performance).

b) Based on the statistics above, the $t$ count value for the work environment variable is 2.878 . This result means that it is greater than the table value, which is 1.991, obtained from $(n-k=80-4=76)$ with a significance level of $a=5 \%$. Then the sig value is obtained at 0.005 , which means it is smaller than the significance level $\mathrm{a}=0.05$. Therefore, it is concluded that $\mathrm{t}$ count $>\mathrm{t}$ table $(2,878>1,991)$. Moreover, the significance level is $0.005<0.05$, so the decision is taken $\mathrm{HO}$ is rejected, and $\mathrm{Ha}$ is accepted. This result means that the independent variable (work environment) has a positive and significant effect on the dependent variable (employee performance).

c) Based on the statistics above, the t-value for the motivation variable is 3.088. This result means that it is greater than the table value, which is 1.991 , obtained from $(\mathrm{n}-\mathrm{k}=80-4=76)$ with a significance level of $\mathrm{a}=5 \%$. Then the sig value is obtained at 0.003 , which means it is smaller than the significance level $\mathrm{a}=0.05$. Therefore, it is concluded that $\mathrm{t}$ count $>\mathrm{t}$ table $(3,088>1,991)$. Furthermore, the significance level is $0.003<0.05$, so the decision is taken $\mathrm{HO}$ is rejected, and $\mathrm{Ha}$ is accepted. This result means that the independent variable (motivation) has a positive and significant effect on the dependent variable (employee performance).

\section{Hypothesis F Test (Simultaneous)}

Anova

\begin{tabular}{|l|l|r|r|r|r|r|}
\hline \multicolumn{2}{|c|}{ Model } & Sum Of Squares & Df & Mean Square & F & Sig. \\
\hline \multirow{3}{*}{1} & Regression & 1307.874 & 3 & 435.958 & 34.636 & $.000^{\mathrm{b}}$ \\
\cline { 2 - 7 } & Residual & 956.614 & 76 & 12.587 & & \\
\cline { 2 - 7 } & Total & 2264.487 & 79 & & & \\
\hline
\end{tabular}

A. Dependent Variable: Kk

B. Predictors: (Constant), M, Lk, Gk

Source: SPSS V 25 Data Processing Results

After the F-test, the F-count is 34,636, while the value of F-table ( $\mathrm{dfl}=\mathrm{k}-1$; $\mathrm{df} 2=\mathrm{n}-\mathrm{k})$ or $(\mathrm{df1} 4-1=3 ; \mathrm{df} 2=80-4=76)$. The results obtained are F-count $>\mathrm{F}-$ table $(34.636>2.72)$, thus Ho is rejected and $\mathrm{H} 1$ is accepted. With a significant level of $0.000(0.000<0.05)$. It can be concluded that leadership style (X1), work environment (X2) and motivation (X3) have a positive and significant effect on employee performance variables (Y) at PT. Djaya Sinar Propertindo.

\section{CONCLUSION}

Based on the research and discussion conducted regarding leadership style, work environment, and motivation on employee performance, the following conclusions are obtained: 
1. There is a positive and significant influence between leadership style on employee performance at PT Djaya Sinar Propertindo. It is known that $\mathrm{t}$ count $2.152>$ $1.991 \mathrm{t}$ table and the significance value is $0.035<0.05$.

2. There is a positive and significant influence between the work environment on employee performance at PT Djaya Sinar Propertindo. It is known that t count $2.878>$ $1.991 \mathrm{t}$ table and the significance value is $0.005<0.05$.

3. There is a positive and significant influence between motivation on employee performance at PT Djaya Sinar Propertindo. It is known that $\mathrm{t}$ count $3.088>1.991 \mathrm{t}$ table and the significance value is $0.003<0.05$.

4. There is a positive and significant influence between leadership style, work environment, and motivation on employee performance at PT Djaya Sinar Propertindo. The value of count $>\mathrm{f}$ table where $34,636>2.72$. When viewed from the comparison of the significance value, the obtained significance value of 0.000 compared with a significance value of $5 \%(0.05)$ than $0.000<0.05$.

\section{Recommendations}

Based on the results of research studies that have been carried out, the authors intend to provide suggestions that may be useful for companies and employees, namely as follows:

\section{For Companies}

1. Leadership style at PT. Djaya Sinar Propertindo is in good condition. However, it still needs to be improved based on the results of respondents' answers, namely for the statement "The boss submits all decisions and policies regarding work to employees," it is hoped that the company can increase trust in employees by involving employees in making decisions and policies regarding work. This point can make employees feel confident and exert all their abilities to the maximum. Meanwhile, what needs to be maintained based on the results of the respondents' answers are the statement "The boss gives clear and detailed orders to employees in carrying out their duties and work" and for the statement "The boss gives freedom to employees to determine for themselves the method or technique of carrying out a good job."

2. The working environment at PT. Djaya Sinar Propertindo is in good condition. However, it still needs to be improved based on the results of respondents' answers, namely for the statement "Infrastructure is quite supportive," it is hoped that the company can provide better market facilities and what employees need. If employees get good infrastructure, employees can work more effectively and efficiently. Meanwhile, based on the results of the respondents' answers, what needs to be maintained is the statement "There are lunch facilities for employees."

3. Motivation at PT. Djaya Sinar Propertindo is in good condition. However, it still needs to be improved based on the results of the respondents' answers, namely for the statement "There are performance allowances, bonuses or incentives given by the company to employees," it is hoped that the company can pay attention to employees 
correctly. Providing allowances or incentives for employees can motivate employees to work better and optimally. Meanwhile, based on the results of the respondents' answers, what needs to be maintained is the statement "Employees have good skills at work."

4. Employee performance at PT. Djaya Sinar Propertindo is in good condition. However, it still needs to be improved based on the results of the respondents' answers, namely for the statement "Employees can complete tasks or jobs with a predetermined time," it is hoped that the company can better condition the number of jobs and the optimal completion time of work according to the level of difficulty of the work so that employees can complete the work correctly by the allotted time. Meanwhile, what needs to be maintained based on the results of the respondents' answers is the statement, "Employees can be responsible if there are problems related to work."

\section{For Employees}

Please pay more attention to things that can improve employee performance to assist in supporting the work of employees in achieving company goals with the best performance results for PT. Djaya Sinar Propertindo.

\section{ACKNOWLEDGEMENT}

1. Head of Magister Management Study Program of Mercu Buana University.

2. Chair and staff of PT. Djaya Sinar Propertindo for the provision of various facilities and conveniences during the research.

\section{REFERENCES}

[1] Armstrong, Michael. (2009). Armstrong's Handbook of Human Resource Management practice $11^{\text {th }}$ edition. United Kingdom: Kogan Page.

[2] Bernardin and Russel. (2000). Human Resources Management. New York: Mc Graw Hill.

[3] Kartono, Kartini. (2001).Leadership Method. Bandung: Alphabeta, cv.

[4] Kartono, Kartini. (2005). Leadership: What is Abnormal Leadership?. Jakarta: PT Raja Grafindo Persada.

[5] Kouzes dan Posner. (2004). HR Management in Public and Business Organizations. Bandung: Alphabeta.

[6] Mangkunegara Prabu Anwar. (2006). Factors Affecting Performance. Bandung: Alphabeta.

[7] Priansa Juni Donni dan Suwatno. (2016). HR Management in Public and Business Organizations. Bandung: Alphabeta, cv.

[8] Priansa Juni Donni. (2018). HR Planning and Development. Bandung: Alfabeta, cv.

[9] Rivai dan Sagala. (2009). HR Planning and Development. Bandung: Alphabeta, cv.

[10] Robbins, Stephen P. (2006). Organization Theory: Structure, Design, and Application. Translated by: Yusuf Udaya. Jakarta: Arcan.

[11] Sedarmayanti. (2011). Build and develop leadership and improve performance to achieve success. Bandung: PT Reflika Aditama. 
[12] Sedarmayanti. (2011). MSDM. Bureaucratic Reform and Civil Service Management. Bandung: PT Refika Adhitama.

[13] Sikula, Andrew F. (2001). Performance Management System. Translated Edition. Jakarta: Gramedia Pustaka Utama.

[14] Veithzal Rivai. (2004). Leadership Tips in the 21st Century. Jakarta: Murai Kencana.

[15] Werther Jr, William B., and Keith Davis. 2008. Human Resources and Personnel Management. Singapore: Mc Graw Hill.

[16] Faraby Kasnul Ichsan. (2018). The Influence of Leadership Style, Work Environment and Work Motivation on Employee Performance at PT Gapura Angkasa in Makassar Hasanuddin International Airport. Vol.5, No. 2. 2018. E-ISSN 2598-398X.

[17] Farizki Ressa Muchamad and Aniek Wahyuati. (2017). The Influence of Work Motivation and Work Environment on the Performance of Medical Employees at RSU Bhakti Rahayu Surabaya. Vol. 6, No. 5, May 2017. e-ISSN: 2461-0593

[18] Guterres Aparicio Luis dan Wayan Gede Supartha. (2016). The Influence of Leadership Style and Work Motivation on Teacher Performance at State Public High School 02 Baucau-Timor Leste. ISSN: 2337-3067.

[19] Naa Abner. (2017). The Influence of Work Environment, Work Motivation and Training on Employee Performance at the Bintuni District Office, Teluk Bintuni Regency. Vol.2, No. 2. August 2017. e-ISSN: 2527-564x.

[20] Pratama Budi Yofanda. (2015). The Influence of Work Motivation and Work Environment on Employee Performance at Regional Water Company (PDAM) Sleman Regency. Essay. Yogyakarta State University.

[21] Setiawan Roy and Mitchael Hutomo Tanuwibowo. (2015). The Influence of Organizational Culture and Work Motivation on Employee Performance at PT Lestari Purnama Perkasa. Vol.3, No.2.

[22] Sunarsi Denok. (2017). The Influence of Leadership Style and Work Discipline on Employee Performance at CV Usaha Mandiri Jakarta. Vol. 1, No. 2. January 2017.

[23] Wasiman. (2018). The Influence of Leadership Style, Motivation and Communication on Employee Performance at Private Hospitals in Batam City. Vol.3, No.1. February 2018.

[24] Widyawati Nurul and Fathur Rosi. (2018). The Influence of Leadership Style, Work Environment, and Motivation on Employee Performance at PT Berhasil Indonesia Gemilang. Vol.7, No.8. August 2018. e-ISSN: 2461-0593. 